\title{
LIBER AMICORUM
}

\author{
ESSAYS IN HONOUR OF \\ PROFESSOR EDWELL KASEKE
} AND DR MATHIAS NYENTI

Marius Paul Olivier Letlhokwa George Mpedi \& Evance Kalula

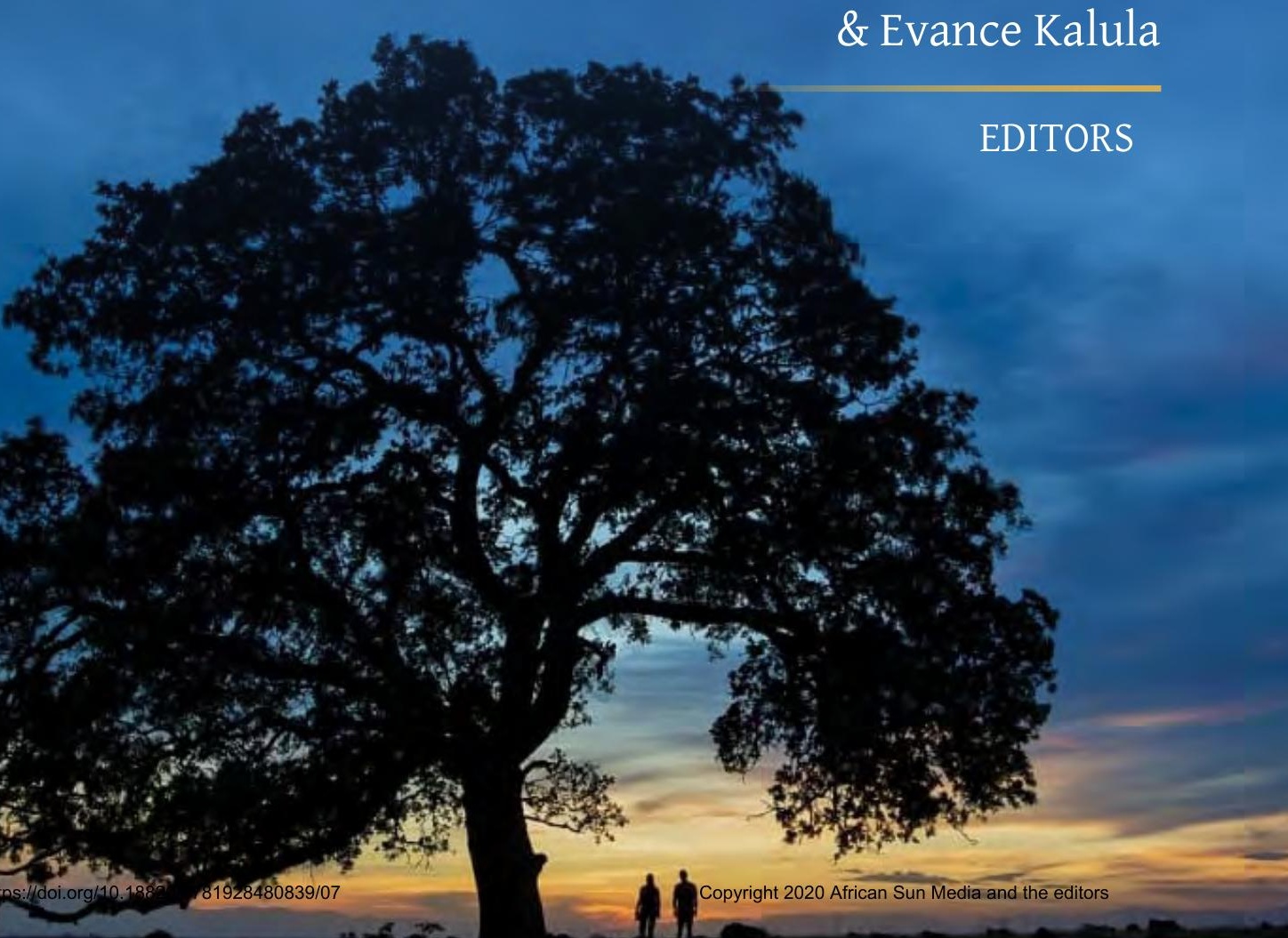




\title{
CHAPTER 7
}

\section{Access to Social Security for Refugees and Asylum Seekers in South Africa: An Analysis of Recent Developments}

\begin{abstract}
The social security position of refugees and asylum seekers in South Africa is fraught with difficulty. Recent cases illustrate some of the key ongoing challenges, demonstrating that such matters frequently require an analysis of multiple aspects of law, potentially including immigration, labour, equality, administrative and social security dimensions. The judiciary's approach has also been appropriately informed by creative and contextual statutory interpretation, more specifically the manner in which the Immigration Act and Refugees Act have been harmonised in their reading. This has ensured that the basic ability to enter the country lawfully exists for the groups of people under consideration (despite the provisions of the Immigration Act). Enhancements in respect of (lawful) access to the country have been complemented by the core judgments in support of the right to work which, read together, lend support for the right to earn a living through wage employment or self-employment (also pending applications for asylum). This opens further prospects for asylum seekers and refugees to make contributions to existing social insurance funds. Such developments appear, however, to fly in the face of the Department of Home Affairs' White Paper on International Migration (2017). Some of the principles expressed in this White Paper appear to conflict with the jurisprudence that has emerged from the Supreme Court of Appeal and Constitutional Court in relation to enhanced protection of refugees and asylum seekers. Such issues should be addressed, along with possible amendments to social security legislation, to provide clarity in respect of the position of asylum seekers, refugees and their family members. Finally, new social security-related legislation being developed, particularly in relation to the National Social Security Fund and National Health Insurance, should expressly address the social security position of refugees and asylum seekers in a progressive manner.
\end{abstract}

Keywords: Asylum seekers, immigration law, jurisprudence, refugees, social security 


\section{1}

\section{Introduction}

The Constitution of the Republic of South Africa, 1996 (the Constitution), states that 'everyone' has the right to have access to social security, including if they are unable to support themselves and their dependants, appropriate social assistance. Despite this, and notwithstanding recent developments in international and regional law, the social security position of refugees and asylum seekers in South Africa is fraught with difficulty. For example, these categories (refugees and asylum seekers) struggle to obtain clarity regarding their actual status in the country (also because of the general conflation of refugees and asylum seekers with so-called economic migrants) and have been forced to approach the courts to access the labour market, education opportunities and social security benefits to which they may be entitled.

A few recent cases illustrate some of the key ongoing challenges, demonstrating that such matters frequently require an analysis of multiple aspects of law, potentially including immigration, labour, equality, administrative and social security dimensions.

This chapter seeks to consider the available jurisprudence emerging in this area against the backdrop of the applicable constitutional provisions, international and regional standards and national legislation and policy developments, as well as to provide some clarity in respect of the complex juxtaposition that is required to appreciate the social security position of these categories of migrants.

\section{2}

\section{An overview of the legal framework}

\subsubsection{The Constitution}

Refugees and asylum seekers are considered to be especially vulnerable groups in South African society, given that they have typically been forced to leave their own homes as a result of persecution, human rights violations and conflict, often subjected to violence and trauma based on personal attributes in the process. ${ }^{1}$ Given South Africa's experience with apartheid, the plight of refugees and asylum seekers is particularly poignant. This partly explains the Constitution's preference for providing most of its array of rights (including human dignity, the right to equality 
and to access social security) to 'everyone', rather than citizens only. ${ }^{2}$ This approach also resonates with the constitutional values that underpin the type of society South Africa strives to be - one steeped in human dignity, the achievement of equality and the advancement of human rights and freedoms.

Significantly, the State must respect, protect, promote and fulfil all the rights contained in the Bill of Rights, many of which apply to refugees and asylum seekers in an interdependent fashion, and any law or policy which is inconsistent with the constitutional protection of such rights (for example, because it amounts to unfair discrimination) would be invalid. As indicated above, section 27(1) of the Constitution promises everyone the right to have access to social security and the state must take reasonable legislative as well as other measures (presumably encompassing well-directed policies and programmes implemented by the executive), within its available resources (i.e. supported by adequate budgetary provisioning), to achieve progressive realisation in this regard. ${ }^{3}$ When it comes to unfair discrimination, it is arguable that immediate remedial steps may be required.

\subsubsection{International law}

South Africa is, in terms of section 231 of the Constitution, bound by international agreements that have been ratified and approved by the South African parliament. A court, tribunal or forum must also consider (all) international law when interpreting the Bill of Rights, including the right to have access to social security on the part of refugees and asylum seekers. ${ }^{4}$ A host of provisions contained in international instruments influence this right, for example:

2 For example, the Constitution provides in section 9 that everyone is equal before the law and has the right to equal protection and benefit of the law, and the state may not unfairly discriminate directly or indirectly against anyone on a range of listed grounds. Although, section 9 of the SA Constitution does not specifically list citizenship as a ground of discrimination, a string of Constitutional Court cases, from as early as Larbi-Odam and others v Member of the Executive Council for Education (North-West Province) and Another [1997] ZACC 16; 1997 (12) BCLR 1655; 1998 (1) SA 745 (CC), dealing with the equality clause contained in the interim constitution, have found that differentiation on the basis of citizenship constitutes discrimination, may infringe the dignity of (categories of) non-citizens and could be unfair on that basis. Also see Khosa and others v Minister of Social Development and Others, Mahlaule and Another v Minister of Social Development [2004] ZACC 11; 2004 (6) SA 505 (CC); 2004 (6) BCLR 569 (CC).

3 Section 27(2). It should also be noted that the rights in the Bill of Rights, including the right to access social security, may be limited in terms of a law of general application to the extent that the limitation is reasonable and justifiable in an open and democratic society based on human dignity, equality and freedom, taking into account all relevant factors.

4 Courts must also, when interpreting any legislation, prefer a reasonable interpretation of that legislation (that is consistent with international law) over any alternative interpretation which may be inconsistent with international law, bearing in mind the recognition of customary international law in South Africa (unless this is inconsistent with the Constitution or an Act of Parliament): Sections 233 and 232 of the Constitution. Section 39(1)(b) requires courts to consider international law when interpreting the Bill of Rights. 


\section{LIBER AMICORUM}

$\sigma \quad$ The Universal Declaration of Human Rights of 1948 provides for the right to social security to everyone, including non-citizens.

$\sigma$ The International Covenant on Economic Social and Cultural Rights, 1966, ratified by South Africa, provides for the right to social security for everyone but also states that "developing countries, with due regard to human rights and their national economy, may determine to what extent they would guarantee the economic rights recognised in the present Covenant to non-nationals" (own emphasis), which arguably should be read restrictively so that states may not draw such distinctions in respect of social and cultural rights. ${ }^{5}$

$\sigma \quad$ Other United Nations (UN) human rights instruments, treaties and conventions ratified by South Africa, including the United Nations Convention on the Status of Refugees (and Protocol Relating to the Status of Refugees), 1951; the Convention on the Rights of Persons with Disabilities, 2006; the International Covenant on Civil and Political Rights, 1966; the Convention on the Rights of the Child, 1989; the Convention on the Elimination of all Forms of Racial Discrimination, 1965; the Convention against Torture and other Cruel, Inhuman or Degrading Treatment or Punishment, 1984, and the Convention on the Elimination of All Forms of Discrimination Against Women, 1979.

$\sigma$ The International Convention on the Protection of All Migrant Workers and Members of Their Families (ICMW) of 1990, which South Africa has still not ratified, protects refugees and asylum seekers against discrimination and provides for equal access to social security, providing specific rights for documented workers. While states may, in the exercise of their national sovereignty, determine who enters and remains within their territory, "Entering a country in violation of its immigration laws does not deprive migrants of the fundamental human rights provided by human rights instruments [...] nor does it affect the obligation of states to protect migrants in an irregular situation." ${ }^{\prime}$ The Human Rights Committee has been explicit in finding that this Convention's rights must, with narrow exceptions, be guaranteed without discrimination between citizens and non-citizens, and specifically that such rights "must also be available to all individuals, regardless of nationality or statelessness, such as asylum seekers, refugees, migrant workers and other persons, who may find themselves in the territory or subject to the jurisdiction of the State Party."

$\sigma$ South Africa has also failed to accept international labour obligations by ratifying any of the migrant-specific International Labour Organization (ILO) conventions. Such conventions, such as the Migration for Employment Convention, No. 97 of 1949; Migrant

5 See the General Comment (No. 19) by the United Nations Committee on Economic, Social and Cultural Rights, containing specific points of reference to the social security position of refugees, asylum seekers and other categories of non-citizens in South Africa, and which notes the importance of establishing bi- and multilateral agreements for coordinating contributory social security schemes for migrant workers.

6 Global Commission for International Migration. 2005. Migration in an Interconnected World: New Directions for Action. Geneva, p. 55.

7 UN Human Rights Committee. The Nature of the General Legal Obligation Imposed on State Parties: General Comment No. 31, par 10. 
Workers (Supplementary Provisions) Convention, No. 143 of 1975; Equality of Treatment (Social Security) Convention, No. 118 of 1962 and Maintenance of Social Security Rights Convention, No. 157 of 1982, typically promote equal treatment and prohibit unfair discrimination against immigrants 'lawfully present' within the territory of a country (but also go beyond this on occasion), also with specific reference to social security. ${ }^{8}$

In terms of section 39 of the Constitution, courts may also consider foreign law (including the best practice experiences of countries on the continent and in the Southern African region) when interpreting the Bill of Rights. From a regional perspective, the African Union (AU) has adopted a Protocol to the Treaty Establishing the African Economic Community Relating to the Free Movement of Persons, Right of Residence and Right of Establishment, to be read with the (revised) AU Migration Policy Framework for Africa, the AU Social Policy Framework, recently adopted Plan of Action (2018-2030) and its own Agenda 2063 (including the establishment of a Continental Free Trade Area). ${ }^{9}$ The Southern African Development Community (SADC) Treaty, Charter of Fundamental Social Rights in SADC and Code on Social Security in SADC make some provision for social security coverage for citizens and residents of different Member States, for example, linking social protection of refugees to the provisions contained in international and regional instruments. ${ }^{10}$ This is supported by the regional migration policy framework in SADC, specifically the Protocol on the Facilitation of Movement of Persons of 2005 (which seeks to facilitate the movement of persons amongst SADC Member States without the need for a visa for a maximum period of 90 days).

\subsubsection{South African legislation}

The Refugees Act (1998) ${ }^{11}$ defines and distinguishes between 'refugees' (including dependants of refugees) and 'asylum seekers' but treats these groups quite differently. An asylum seeker is someone who has arrived in South Africa and

8 Also note, in this regard, the ILO Recommendation Concerning National Floors of Social Protection, 2012 (No. 202), which widens the scope of coverage in order to afford essential social security protection to anyone in the country, and calls for the implementation of a national minimum package of social security guarantees. This should be read with the Social Security (Minimum Standards) Convention, (No. 102 of 1952).

9 Free movement is qualified by the general requirement that the right of a non-national under the Protocol has to be exercised with due regard to the laws and procedures of the host Member State and Member States retain the power to expel, deport or repatriate a national of a Member State "by virtue of a decision taken in accordance with the law in force in the host Member State" (article 21).

10 In so far as bilateral agreements in the region are concerned, Olivier has criticised these agreements for focusing more on the regulation of the flow of migrant labour to South Africa, and for dealing with important social security-related arrangements as a mere by-product: MP Olivier 2012. "Social security: Framework". In: W.A. Joubert et al (eds.). The Law of South Africa (2nd Ed) vol.13(2). LexisNexis: Durban, par 153.

11130 of 1998. 
applied for asylum, that is, for recognition as a refugee, while a refugee is someone who has been granted asylum. ${ }^{12}$ The effect of section 2 of the Act is to permit any person to enter and to remain in the country to seek asylum from persecution on account of race, religion, nationality, political opinion or membership of a particular social group, or a threat to his or her life or physical safety or freedom on account of external aggression, occupation, foreign domination or disruption of public order. ${ }^{13}$ Such provisions intersect with sections of the Immigration Act, 2002. ${ }^{14}$ Section 23 of the Immigration Act and regulation 22 of the regulations provide that the DirectorGeneral may issue an asylum transit visa to any person who arrives at a South African port of entry and claims to be an asylum seeker. The visa is valid for five days and allows the asylum seeker only to travel to the nearest Refugee Reception Office to apply for asylum. ${ }^{15}$ If the application for asylum succeeds, the applicant becomes entitled to all the rights of refugees provided for in section 27 to 34 of the Refugees Act, including the rights to live and work in South Africa and to apply for a permanent residence permit.

The legal position of refugees has evolved to such an extent that, in several respects, they enjoy the same social security treatment as that enjoyed by permanent residents in South Africa. Refugees, therefore, qualify for the constitutionally entrenched right to have access to social security, including appropriate social assistance, as well as access to the other socio-economic rights contained in the Constitution. As far as social assistance is concerned, refugees now enjoy access to social grants on the same basis as citizens and permanent residents, and refugees in need of immediate temporary assistance also qualify for social relief of distress. ${ }^{16}$ Refugees also appear to be generally covered by the Unemployment Insurance Act, 2001 (the UIA), ${ }^{17}$ if they are employed, given that this Act applies to "all employers and employees, other than employees employed for less than 24 hours a month with a particular employer, and their employers". They should also have no difficulty in accessing

\footnotetext{
12 See Ahmed v Minister of Home Affairs [2018] ZACC 39, par 24.

13 See in general, Minister of Home Affairs $v$ Watchenuka [2003] ZASCA 142; [2004] 1 All SA 21 (SCA). The Constitutional Court in Ruta v Minister of Home Affairs [2018] ZACC 52 described this as a remarkable provision and one that was perhaps "unprecedented in the history of our country's enactments", par 24.

1413 of 2002 .

15 Ahmed, par 24 and 25. Once asylum seekers have entered South Africa, they must apply for asylum at a Refugee Reception Office and the Refugee Reception Officer must issue an asylum seeker permit to the applicant pending the outcome of an application for asylum.

16 While the regulations to the Social Assistance Act, 2004 (13 of 2004) reflects this reality, the actual Act itself should be amended to reflect the latest developments in this regard. 
compensation for an occupational injury or disease ${ }^{18}$ and benefit in the event of a road accident. ${ }^{19}$ The latest available discussion document on "Comprehensive Social Security in South Africa" (prepared by the Inter-Departmental Task on Social Security and Retirement Reform) suggests that a future National Social Security Fund (NSSF) should cover (only) 'migrant workers', possibly excluding refugees. ${ }^{20}$ The latest proposals in respect of the introduction of National Health Insurance (NHI) are also restrictive, appearing to provide comprehensive benefits only to citizens and permanent residents, and likely to raise a constitutional challenge if passed in this fashion.

The social security position of asylum seekers is even more constrained, and somewhat similar to that of temporary residents, despite the reality that asylum seekers are often present in the country for a lengthy period. ${ }^{21}$ The difficulties associated with pinpointing the social security position of asylum seekers stems from their status as being present in the country on a transitional basis, and asylum seekers are generally excluded from available social assistance arrangements (in terms of the provisions of the Social Assistance Act). They should at least be covered in respect of road accidents, occupational injuries and diseases and unemployment insurance on the same basis as discussed above in respect of refugees. The NSSF would appear not to contemplate the participation of asylum seekers and comprehensive health insurance benefits will apparently not be extended to asylum seekers in terms of the proposed NHI system, a matter considered in the analysis, below. Of course, once a person's asylum-seeking status is withdrawn, the position would change and that person would generally be considered to be an undocumented/irregular/illegal migrant and restrictions to such a person's social security entitlements would more easily be considered to be proportional and reasonable.

Recent decisions on the right to access employment on the part of asylum seekers and refugees build on the core jurisprudence and hold potentially significant social security consequences. Some of these cases, three cases identified as forming the core jurisprudence and four cases decided during the last two years, are discussed below.

18 In terms of the Compensation for Occupational Injuries and Diseases Act, 1993 (130 of 1993), given that section 16 provides that the compensation fund moneys shall be applied towards "the payment of compensation, the cost of medical aid or other pecuniary benefits to or on behalf of or in respect of employees in terms of this Act where no other person is liable for such payment".

19 Road Accident Fund Act 56 of 1996.

20 Inter-departmental Task Team on Social Security and Retirement Reform Comprehensive Social Security in South Africa: Discussion document (version 11.9). 2012. Available online: https://bit.ly/3cZVTPs [accessed on 25 June 2019].

21 According to the Department of Home Affairs' White Paper on International Migration, 2017, the asylum seeker regime is being abused by economic migrants resulting in over $90 \%$ of the claims for asylum being rejected. The high demands being placed on the asylum seeker and refugee regime are, according to this document, negatively affecting the country's ability to provide protection services to migrants in need of protection, p. 59. 


\section{3}

\section{South African jurisprudence}

\subsubsection{The core jurisprudence}

In Minister of Home Affairs $v$ Watchenuka, ${ }^{22}$ the Supreme Court of Appeal drew a distinction between limiting the right of asylum seekers to undertake employment in all instances and limiting this right where "employment is the only reasonable means for the person's support". In the latter instance, the court highlighted that this would amount to not only a restriction upon the person's capacity for selffulfilment, but a restriction upon his or her ability to live without positive humiliation and degradation..$^{23}$ The Court concluded that there would be circumstances in which it would be unlawful to prohibit applicants for asylum from taking up employment or to study pending the outcome of their applications, and directed the Standing Committee for Refugee Affairs to consider and determine whether the applicants in the case should be permitted to undertake employment and study.

The Constitutional Court referred to this decision in considering the issue of the right of refugees to work in the security industry in South Africa in Union of Refugee Women v Director: Private Security Industry Regulatory Authority. ${ }^{24}$ The majority of the Court held that while differentiation between citizens and permanent residents, on the one hand, and all other foreigners, on the other, has a rational foundation and serves a legitimate governmental purpose, the legislation in question only limited the right to choose employment in respect of the private security industry, in no way preventing refugees' rights to seek employment in other industries.

In Somali Association of South Africa $v$ Limpopo Department of Economic Development, Environment and Tourism, ${ }^{25}$ the Supreme Court of Appeal specifically considered the vulnerable position of asylum seekers and refugees against the backdrop of South Africa's international obligations and the rights to equal treatment (with South African citizens) and dignity. It also considered both the Watchenuka and Union of Refugee Women judgments, holding that neither had considered section 22 of the Constitution to place a blanket prohibition on asylum seekers and refugees seeking employment. ${ }^{26}$ The court concluded that asylum seekers and refugees were entitled to earn a living by way of self-employment, and, consequently, to apply for a new business or trading licences, apply for renewal of such licenses and apply for and renew written consent to operate tuck-shops or spaza shops in terms of the

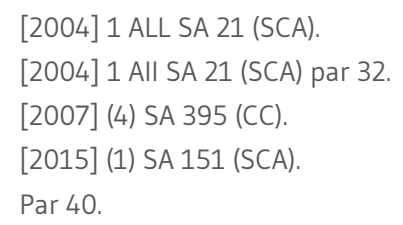


applicable legislation. In support of this, the court referred to refugees as having "a special vulnerability, since refugees are by definition persons in flight from the threat of serious human rights abuse." ${ }^{27}$ As such, it decided to extend the Watchenuka principle pertaining to wage-earning employment to self-employment as follows:

Put differently, if, because of circumstances, a refugee or asylum seeker is unable to obtain wage-earning employment and is on the brink of starvation, which brings with it humiliation and degradation, and that person can only sustain him - or herself by engaging in trade, that such a person ought to be able to rely on the constitutional right to dignity in order to advance a case for the granting of a licence to trade as aforesaid [...] (and not) to condemn the appellants to a life of humiliation and degradation. ${ }^{28}$

\subsubsection{The recent jurisprudence}

In the recent case of Ahmed $v$ Minister of Home Affairs, ${ }^{29}$ the Constitutional Court had the opportunity to consider whether asylum seekers, including those whose applications for refugee status have been refused, are eligible to apply for other visas and immigration permits in terms of the Immigration Act. The judgment clearly demonstrates the close connection between refugee and immigration law, and specifically focused on a governmental directive imposing a blanket ban on asylum seekers applying for temporary or permanent residence visas under the Immigration Act. The court concluded that a blanket ban would be ultra vires the Immigration Act and that asylum seekers must be allowed to apply for visas or permits under the Immigration Act, to be granted the visa or permit if they meet the requirements of that Act and that applicants could request a Ministerial waiver from the requirement that an application for a visa must be made from outside the borders of the country. ${ }^{30}$ One of the consequences of the court's judgment appears to be that nothing is preventing an asylum seeker from applying for a visa or permit under the Immigration Act without a valid passport. ${ }^{31}$

Interestingly, very recent news reports (referring to an unreported settlement agreement arising from a court action in a matter involving the Scalabrini Centre of Cape Town) suggest that protection for asylum seekers and refugees have now been extended to their families, given that dependants may apply to be documented either through so-called family-joining or on their own terms. ${ }^{32}$ The implications appear to be that refugee and asylum seeker families can be documented together to ensure their rights to family unity and dignity in South Africa (and avoiding such

Par 33.

28 Par 43.

29 [2018] ZACC 39.

30 Ahmed par 60.

31 Ahmed par 62.

32 Cape Times. Court eases plight of refugees, 21 June 2019. Available online: https://bit.ly/2GqG8W6 [accessed on 1 July 2019]. 
persons from unnecessarily being in an undocumented, and even more vulnerable, state) ${ }^{33}$ This has potentially far-reaching implications for the security and social security position of such persons, including reduced likelihood of arrest and detention due to the absence of documentation, enhanced prospects of obtaining legal work and broader social protection benefits such as enhancing the likelihood of school attendance. A set of standard operating procedures have consequently been agreed between the Department of Home Affairs and civil society, allowing the documentation of family members of asylum seekers and refugees upon proof of basic documentation such as a marriage certificate or birth certificate, regardless of where this may have taken place. It is apparently also possible for this outcome to be achieved on the presentation of an affidavit in the absence of such basic documentation (although the Department may request a DNA test in cases of serious doubt).

In Ruta, the Constitutional Court recently addressed, to some extent, the general question as to how the Refugees Act and Immigration Act harmonise with one another. The Court found that enabling the applicant and asylum seekers in his position to have their status determined under the Refugees Act did not result in the conclusion that everyone or anyone has the right to enter the Republic anywhere across South African borders - a concern of the Minister of Home Affairs in that particular case. The court found specifically that the Immigration Act could not be read to trump the provisions of the Refugees Act, and held that the two pieces of legislation, which contained a gap in respect of asylum seekers not entering through official ports of entry, should be read in harmony: ${ }^{34}$

\begin{abstract}
Though an asylum seeker who is in the country unlawfully is an 'illegal foreigner' under the Immigration Act, and liable to deportation, the specific provisions of the Refugees Act intercede to provide imperatively that, notwithstanding that status, his or her claim to asylum must first be processed under the Refugees Act [...] the Immigration Act affords an immigration officer a discretion whether to arrest and detain an illegal foreigner. That discretion must, in the case of one seeking to claim asylum, be exercised in deference to the express provisions of the Refugees Act that permit an application for refugee status to be determined. (own emphasis)
\end{abstract}

Significantly, according to the court, the realities of migration in Africa and elsewhere are more complex than that envisioned by the Immigration Act, which catered only for one narrow category of refugees (namely those arriving at a

33 Also see the recent decision in Nandutu v Minister of Home Affairs [2019] ZACC 24, in the context of regulation 9(9)(a) of the Immigration Act not providing foreign spouses and children of citizens and permanent residents with the option of changing their visa status from within the country. The judgment explains the intertwined relationship between human dignity and familial rights and how they function alongside notions of state security and legislative regimes that seek to protect persons within the borders of South Africa.

34 Ruta par 43, 46 (footnotes omitted in the quotation). 
recognised port of entry)..$^{35}$ Delays in seeking refugee status cannot function as an absolute disqualification from initiating the asylum application process. ${ }^{36}$

A recent unreported Equality Court case, Saddiq $v$ Department of Labour, ${ }^{37}$ has specifically considered the case of an asylum seeker who had been employed for more than two years and made contributions to the Unemployment Insurance Fund (UIF), been dismissed but not received benefits from the Department of Labour on the basis that the Department had no system to accept or pay asylum seekers claiming unemployment insurance benefits. ${ }^{38}$ The Magistrate decided the case based on the Promotion of Equality and Prevention of Unfair Discrimination Act, 2000, ${ }^{39}$ found the applicant had been the victim of unfair discrimination and awarded R30 000 as damages in addition to the UIF benefits to which he was entitled. Importantly, the Department of Labour was ordered to correct its computer system to allow any asylum seeker who contributed to the fund to receive benefits in future.

\section{4}

\section{Analysis and conclusion}

The Constitution draws no distinction between citizens, refugees and asylum seekers in respect of the provision of social security, which is meant to be accessible to 'everyone', and legislation exists in support of this right. Practically speaking, however, it has required significant intervention on the part of the courts to give some substance to this promise. The platform for this has been an appreciation of the realities of migration and appropriate emphasis being placed on the 'special vulnerability' of asylum seekers and refugees given that they are often traumatised and in flight from serious human rights abuses. ${ }^{40}$

While courts cannot be blind to the realities of large-scale migration to desirable destination countries, including South Africa (which resulted in governmental departments being overburdened, abuses in the system, and even adverse public opinion), the applicable legislation has increasingly been interpreted, in line with constitutional and international law principles, to afford greater protection to asylum seekers and refugees, in an attempt to avoid the possibility of undue disruption of a life of human dignity. ${ }^{41}$ There is a direct correlation between this type of life and access to social protection, including access to health, educational

35 Ruta par 49.

36 Ruta par 56.

37 Equality Court for the sub-district of Emfuleni EQ 04/2017.

38 Saddiq v Department of Labour (Equality Court for the sub-district of Emfuleni) EQ 04/2017.

394 of 2000.

40 Ruta par 48.

41 Saidi v Minister of Home Affairs [2018] ZACC 9 par 18. 
and other facilities, and social security (in addition, of course, to the protection of civil liberties including protection from deportation, violation of rights to freedom and security of the person and the like). ${ }^{42}$

The judiciary's approach has also been appropriately informed by creative and contextual statutory interpretation, more specifically how the Immigration Act and Refugees Act have been harmonised in their reading. ${ }^{43}$ This has ensured that the basic ability to enter the country lawfully exists for the groups of people under consideration (despite the provisions of the Immigration Act). This development is not insignificant. As the Constitutional Court noted in Ruta, an appreciable number of asylum seekers are informal cross-border migrants who do not arrive at recognised ports of entry and are not able to claim "desktop-afforded privileges". ${ }^{44}$ As a result, the court, in this case, held that asylum seekers should at least have their applications for asylum (in terms of the Refugees Act) processed prior to possible deportation (in terms of the Immigration Act).

The ability of families joining asylum seekers in accessing South African shores lawfully and with the minimum bureaucracy has also been given a massive boost by the recent agreement following a court action in the Scalabrini Centre of Cape Town case. The consequences are far-reaching, permitting family members of asylum seekers to receive the necessary documentation to be in the country lawfully despite themselves only being able to provide the most basic of documentation demonstrating their familial links (such as a birth certificate, marriage certificate or even only an affidavit). In addition, following the judgment in Ahmed, asylum seekers can apply for temporary and permanent residence visas (even without a passport), despite the Department of Home Affairs' White Paper on International Migration, 2017, (the White Paper) suggesting that this would be problematic.

To these enhancements in respect of (lawful) access to the country must be added the core judgments in support of the right to work in Watchenuka, Union of Refugee Women and Somali Association of South Africa, which, read together, lend support for the right to earn a living through wage employment or self-employment (also pending applications for asylum). This opens further prospects for asylum seekers and refugees to make contributions to existing social insurance funds (as occurred in the Saddiq case). Again, these developments appear to contradict the White Paper.

42 Ibid. In this case, the majority of the Constitutional Court concluded that a Refugee Reception Officer does have the power to extend the permit provided for in section 22(1) of the Refugees Act pending finalisprofation of proceedings for the judicial review, in terms of the Promotion of Administrative Justice Act 3 of 2000, of a decision made in terms of the Refugees Act refusing an application for asylum made in terms of section 21(1) of the Refugees Act.

43 The Constitutional Court went beyond this in Ruta, holding that the Refugees Act is the "governing legislation" in the frequent cases where asylum seekers do not enter through official ports of entry: Ruta par 53-54.

44 Ruta par 50. 
This is not to imply that the White Paper, which has been criticised as being a relic of the Jacob Zuma presidency and critically flawed, ${ }^{45}$ is only restrictive in its approach (despite this document having been finalised prior to the slew of recent cases that have been analysed). ${ }^{46}$ The White Paper, for example, recognises that:

$\sigma$ South Africa urgently requires a robust, progressive vision of the benefits of wellmanaged international migration.

$\sigma \quad$ It is neither desirable nor possible to stop or slow down international migration.

$\sigma$ International migration, in general, is beneficial if it is managed in a way that is efficient, secure and respectful of human rights.

$\sigma$ Management of asylum seekers and refugees, including refugee protection and provision of basic services to these categories of non-citizens humanely and securely, is a core strategic issue.

Unfortunately, and despite a lone sentence suggesting that provision of social security and portability of social security benefits will be facilitated, the list of legislation considered by the Department in formulating this White Paper excludes most social security-related legislation (only referencing the UIA). Similarly, the international instruments taken into consideration exclude those relating to social security and, unsurprisingly given these omissions, the analysis contained in the document in relation to refugees and asylum seekers falls short of properly describing and explaining the social security position of these categories of noncitizens, although there is some suggestion that basic needs of asylum seekers will be catered in asylum processing centres.

Importantly, some of the principles expressed in the White Paper appear to conflict with the jurisprudence that has emerged from the Supreme Court of Appeal and Constitutional Court in relation to enhanced protection of refugees and asylum seekers. The White Paper, for example, states that asylum seekers will only be allowed to work and study in exceptional circumstances when they have cases under judicial review. This is a matter that should be addressed, along with possible amendments to social security legislation to provide clarity in respect of the position of asylum seekers, refugees and (particularly given the developments in Scalabrini Centre of Cape Town) their family members (including possible access to social assistance for asylum seekers who are children, older persons or disabled in addition to the basic support presently on offer).

45 G, Eisenberg. "Immigration White Paper critically flawed" Mail and Guardian. 9 November 2018. Available online: https://bit.ly/2GHdsrO [accessed on 1 July 2019].

46 The Government's "Vision 2030" and National Development Plan, which has been adopted as a macro policy guiding the development of new public policies, legislation and strategies, for example, provides that South Africans must embrace international migration for development while guarding sovereignty, peace and security. 
Finally, new social security-related legislation being developed, particularly in relation to the NSSF and NHI, should expressly address the situation of refugees and asylum seekers. The NHI Bill, ${ }^{47}$ in particular, only provides for comprehensive health benefits for citizens and permanent residents, providing limited benefits for refugees and asylum seekers (despite the Refugees Act providing that refugees are entitled to the same basic health services as South African citizens). This is a retrogressive development and one likely to be met with a constitutional challenge given the constitutional rights to social security and health care services. 


\subsection{Bibliography}

\subsubsection{Legislation}

Compensation for Occupational Injuries and Diseases Act, 130 of 1993.

Immigration Act, 13 of 2002.

National Health Insurance Bill, 2018. GG No 636 of 21 June 2018.

Promotion of Equality and Prevention of Unfair Discrimination Act 4 of 2000.

Refugees Act, 130 of 1998.

Road Accident Fund Act, 56 of 1996.

Social Assistance Act, 13 of 2004.

The Constitution of the Republic of South Africa, 1996.

Unemployment Insurance Act, 63 of 2001.

\subsubsection{Case Law}

Ahmed v Minister of Home Affairs [2018] ZACC 39.

Minister of Home Affairs $v$ Watchenuka [2003] ZASCA 142; [2004] 1 All SA 21 (SCA).

Nandutu v Minister of Home Affairs [2019] ZACC 24.

Ruta v Minister of Home Affairs [2018] ZACC 52.

Saddiq $v$ Department of Labour (Equality Court for the sub-district of Emfuleni) EQ 04/2017.

Saidi v Minister of Home Affairs [2018] ZACC 9.

Somali Association of South Africa $v$ Limpopo Department of Economic Development, Environment and Tourism [2015] (1) SA 151 (SCA).

Union of Refugee Women v Director, Private Security Industry Regulatory Authority [2007] (4) SA 395 (CC).

\subsubsection{Online sources}

G, Eisenberg. "Immigration White Paper critically flawed" Mail and Guardian.

9 November 2018. Available online: https://bit.ly/2GHdsrO [accessed on 1 July 2019].

Inter-departmental Task Team on Social Security and Retirement Reform Comprehensive Social Security in South Africa: Discussion document (version 11.9). 2012. Available online: https://bit.ly/3cZVTPs [accessed on 25 June 2019]. 


\section{LIBER AMICORUM}

Cape Times. Court eases plight of refugees, 21 June 2019. Available online: https://bit.ly/2GqG8W6 [accessed on 1 July 2019].

\subsubsection{International instruments}

Global Commission for International Migration. 2005. Migration in an Interconnected World: New Directions for Action. Geneva.

UN Human Rights Committee. 2004. General Comment on The Nature of the General Legal Obligation Imposed on State Parties (No. 31.).

United Nations Committee. 2007. General Comment on Economic, Social and Cultural Rights (No. 19).

International Labout Organization (ILO). 2012. Recommendation Concerning National Floors of Social Protection (No. 202).

Social Security (Minimum Standards) Convention, (No. 102 of 1952).

\subsubsection{Policy documents}

Department of Home Affairs. 2017. White Paper on International Migration. 